\title{
Holocene sea level change in Malta
}

\author{
Stefano Furlani ${ }^{\text {a,b,* }}$, Fabrizio Antonioli ${ }^{c}$, Sara Biolchi ${ }^{\text {a,d }}$, Timothy Gambin ${ }^{\text {e,f }}$, Ritienne Gauci ${ }^{\mathrm{e}}$, \\ Valeria Lo Presti ${ }^{g}$, Marco Anzidei ${ }^{\text {h}}$, Stefano Devoto ${ }^{\mathrm{d}}$, Mariarita Palombo ${ }^{\mathrm{i}}$, Attilio Sulli ${ }^{\mathrm{g}}$ \\ a Dipartimento di Matematica e Geoscienze, Università degli Studi di Trieste, Italy \\ b Dipartimento di Geografia “G. Morandini”, Università di Padova, Italy \\ ${ }^{\mathrm{c}}$ ENEA, Roma, Italy \\ d Dipartimento di Scienze della Terra, Università degli Studi di Modena e Reggio Emilia, Modena, Italy \\ e University of Malta, Malta \\ ${ }^{\mathrm{f}}$ Aurora Trust, Malta \\ ${ }^{\mathrm{g}}$ Dipartimento di Scienze della Terra e del Mare, Università di Palermo, Italy \\ h INGV, Italy \\ i Dipartimento di Scienze della Terra, Università di Roma “La Sapienza”, Italy
}

\section{A R T I C L E I N F O}

Article history:

Available online 25 February 2012

\begin{abstract}
A B S T R A C T
A multidisciplinary approach has been applied to study sea level changes along the coast of Malta using data collected from underwater archaeological remains. The elevation of archaeological markers have been compared with predicted sea level curves providing new bodies of evidence that outline the vertical tectonic behaviour of this region, allowing estimation of the relative sea level changes that occurred in this area of the Mediterranean since the Bronze Age. During the Roman Age, sea level was at $-1.36 \pm 0.1 \mathrm{~m}$, while in the Midde Age it was at $-0.56 \pm 0.2 \mathrm{~m}$, in agreement with previous estimations for the Mediterranean region. Data indicate that Malta was tectonically stable during the studied period. The occurrence of the present-day notch along the coasts of the island indicates recent vertical stability of the area. The lack of MIS 5.5 deposits all over the island could simply be due to high rates of erosion, as its coasts are highly exposed to storm waves, rather than tectonic movements. However, even very slight vertical movements could completely remove field evidence. The relative stability of the Maltese Islands allowed a first attempt to provide a palaeoenvironmental reconstruction of its coasts at different time windows since the Last Glacial Maximum. The results have been used to infer time and mode of mammal dispersal to the island during the Pleistocene.
\end{abstract}

(c) 2012 Elsevier Ltd and INQUA. All rights reserved.

\section{Introduction}

Relative sea level changes along the Mediterranean coasts have been the subject of several papers during the last decade (Flemming, 1969; Lambeck et al., 2004a; Lambeck and Purcell, 2005; Antonioli et al., 2007, 2009). Few archaeological or geomorphological data have been considered to evaluate sea level changes in Malta, although both geomorphological evidence and the study of coastal settlements could provide useful data. Although the Geological Map of Malta (Oil Exploration Directorate, 1993) and Hunt (1996) reported the occurrence of marine Quaternary deposits above mean sea level in the northern part of the island, no dating was provided. Trenchmann (1938) and Hunt (1996) reported

\footnotetext{
* Corresponding author. University of Trieste, Department of Geosciences, via Weiss 2, Trieste, Italy.

E-mail address: sfurlani@units.it (S. Furlani).
}

the presence of marine Quaternary deposits, while Paskoff and Sanlaville (1978) and Magri (2006) suggested an absence of MIS 5.5 deposits on the island because of Quaternary subsidence and tilting towards the northeast.

Although no detailed underwater surveying on coastal archaeological remains has been carried out, local researchers provide some useful observations. Zammit (1928) and Abela (1999) studied the Bronze Age pits at Birzebbugia, which are similar to the pits noted at Borg in-Nadur (other local Bronze Age remains). However, as suggested by Biolchi et al. (2011), the elevation of these pits represents an upper limit, as they are not directly related to sea level, although they had to remain above it. With regards to the coastal remains from the Roman period, no scientific works have been carried out.

Recent papers have shown that coastal archaeological data are a powerful tool to evaluate the sea level changes and the related vertical tectonic movements since historical times (Pirazzoli et al., 1996; Lambeck et al., 2004b; Antonioli et al., 2007; Scicchitano 
et al., 2008; Auriemma and Solinas, 2009). Sea level change is the sum of eustatic, glacio-hydroisostatic and tectonic movements: the first is global and time-dependent, and the latter two vary with location, sediment load, compaction and anthropic factors (Lambeck et al., 2004a). The glacio-hydro-isostatic component of post-glacial sea level rise has been recently predicted and compared with field data at several coastal sites around the Italian coasts (Lambeck et al., 2004a; Antonioli et al., 2007, 2009) and for other areas of the Mediterranean Sea (Anzidei et al., 2011a, 2011b), providing an estimate of the rates of the current vertical tectonic motion.

Following systematic surveying of the coasts of Malta through direct underwater observations, this study aims at providing new data on coastal archaeological remains and at discussing the Holocene sea level change and vertical tectonic rates. On the basis of the relative tectonic stability of Malta since the Last Glacial Maximum (Lambeck et al., 2011), a palaeoshoreline reconstruction has been provided since $20 \mathrm{ka}$ BP. This can also provide an essential key for a better understanding of the sea level changes that occurred during the Middle and Late Pleistocene, which permitted discrete colonization events of the island by both large and small mammals.

\section{Geological framework}

The Maltese Islands (Fig. 1) developed in the Pelagian Block (Sicily Channel), a large area located between Sicily and North Africa, where the wide continental shelves (Adventure Bank and Hyblean-Pelagian to the north, Tunisian and Kerkenna to the south) are separated by a gently dipping slope. The latter is cut by three NW-SE striking deep sectors, known as Pantelleria, Malta and Linosa Graben.

The Sicily Channel is characterized by thinned continental lithosphere (60-70 km), shallow Moho depth (20-25 km), high heat flow, positive Bouguer anomalies and significant volcanic activity associated with magnetic anomalies (Della Vedova et al., 1989). The palaeogeographic evolution of the Pelagian Block is characterized by a widespread Triassic carbonate platform resting on a Permian shallow to deep water domain. Transtensional tectonics opened large basins during the late Triassic-Liassic. The

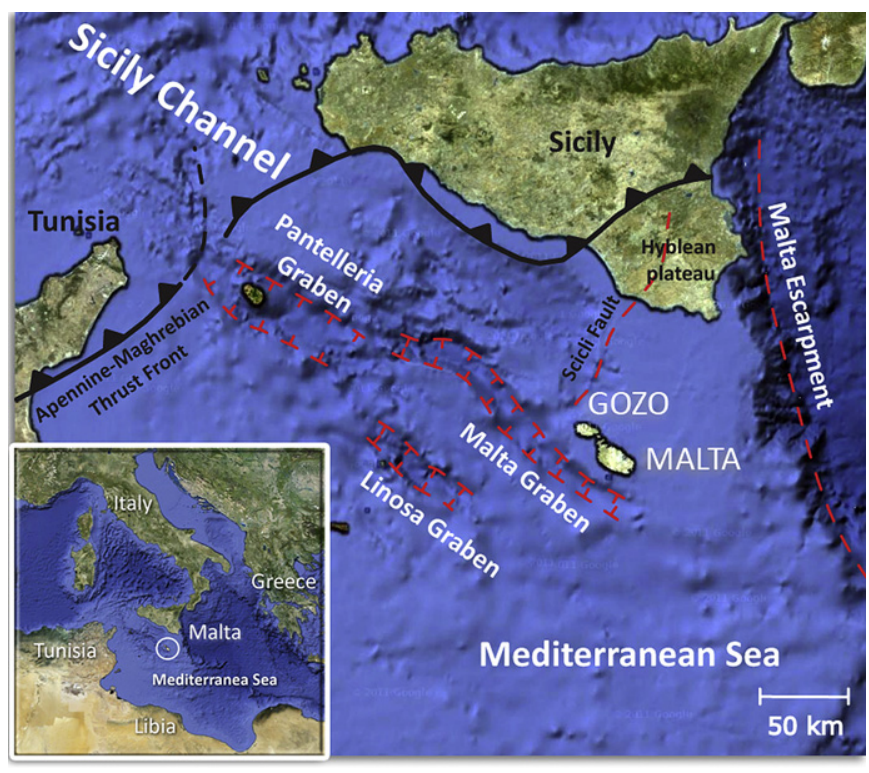

Fig. 1. Location map of the study area with major thrusts and faults (Google Maps). area was a pelagic domain until the Paleogene, with the exception of the Lampedusa and Malta sectors, where shallow water conditions prevailed until the Miocene. In the Maltese Islands, a sedimentary sequence represented by carbonate rocks from Upper Oligocene to Upper Miocene crops out. It is subdivided in four formations (Fig. 2): Lower Coralline Limestone Formation (Chattian), Globigerina Limestone Formation (Aquitanian-Early Langhian), on which the archaeological sites are located, Blue Clay Formation (Langhian-Tortonian), and Upper Coralline Limestone Formation (Late Tortonian-Early Messinian) (Pedley et al., 1978). Stratigraphic observations inferred from the Naxxar wells (for hydrocarbon exploration; Dart et al., 1993), point out that the unexposed sedimentary succession, more than $2800 \mathrm{~m}$ thick, starts with Mesozoic (Cretaceous) shallow water carbonates (Naxxar dolomites), probably resting on a Triassic-Jurassic sequence. The Quaternary deposits consists of continental successions valley loams and breccias and ossiferous deposits in caves and fissures (Trenchmann, 1938) or very thin surficial deposits, such as red soils and colluvial sediments (Pedley, 2011).

The region can be considered as the foreland of the SicilianMaghrebian chain and displays a tectonic evolution, mainly during the last $5 \mathrm{Ma}$, with the latter being a matter of controversial interpretation. It is believed to be subject either to transtensional (both right- and left-lateral) and/or extensional tectonics (Finetti and Del Ben, 1986; Jongsma et al., 1987) or to rifting processes (Grasso et al., 1993; Catalano et al., 1994). The rifting processes could have produced two different systems: 1) NE-SW trending faulting during the early Miocene, with 15\% extension and accompanied by crustal thinning; 2) NW-SE trending faulting, initiated during the Late Miocene-Early Pliocene and still active, with a right lateral component (Illies, 1981). The Malta Escarpment is a major geomorphological feature separating the Hyblean-Malta plateau, resting on continental crust, from the deep Ionian Basin, believed to lie on an old oceanic realm (Catalano et al., 2000).

The Sicily Channel (Fig. 1) underwent folding during the Miocene, probably due to a weak compressional stress field, responsible for the formation of large NW-SE anticlines which collapsed along the Malta, Pantelleria and Linosa Graben (Catalano et al., 1994). This event is coeval to the arching of the Hyblean foreland, probably connected to the advancing of the Sicilian chain. The graben is filled by Plio-Pleistocene deposits, which display a deformational pattern that supports both extensional (rollover anticlines) and transpressional or inversion tectonics.

The Malta Graben is a large basin $1600 \mathrm{~m}$ deep, WNW-ESE trending, with a sigmoidal shape, which merges to the west with the Pantelleria trough. Listric normal faults opened it after the Messinian. It is filled by about $1500 \mathrm{~m}$ thick Plio-Pleistocene clastic deposits, in which two sequences, separated by a strong angular unconformity, can be identified. A severe downfaulting affected also the most recent deposits.

An end-Calabrian Stage (Emilian Sub-Stage) marine surface erosion recognized in the Maltese islands could confirm that the tectonic event responsible for both the reactivation of the Graben systems during late Messinian-middle Pliocene, and also the uplift of the islands, ceased well before the early Calabrian. Subsequent minor regional uplift, sea level fluctuations and subaerial weathering processes contributed in shaping the present morphology of the islands (Pedley, 2011).

The Maltese Islands are believed to have a low seismicity, linked mainly to intraplate stress along almost vertical extensional faults pertaining to the rifting process and subordinately to the activity of the Malta Escarpment and the Scicli strike-slip fault (Fig. 1). Earthquake activity is generally characterized by small magnitude events (Pedley et al., 2002), the strongest being recorded in 1693 (Galea, 2008), while the most recent (ML 4.1) occurred April 24, 


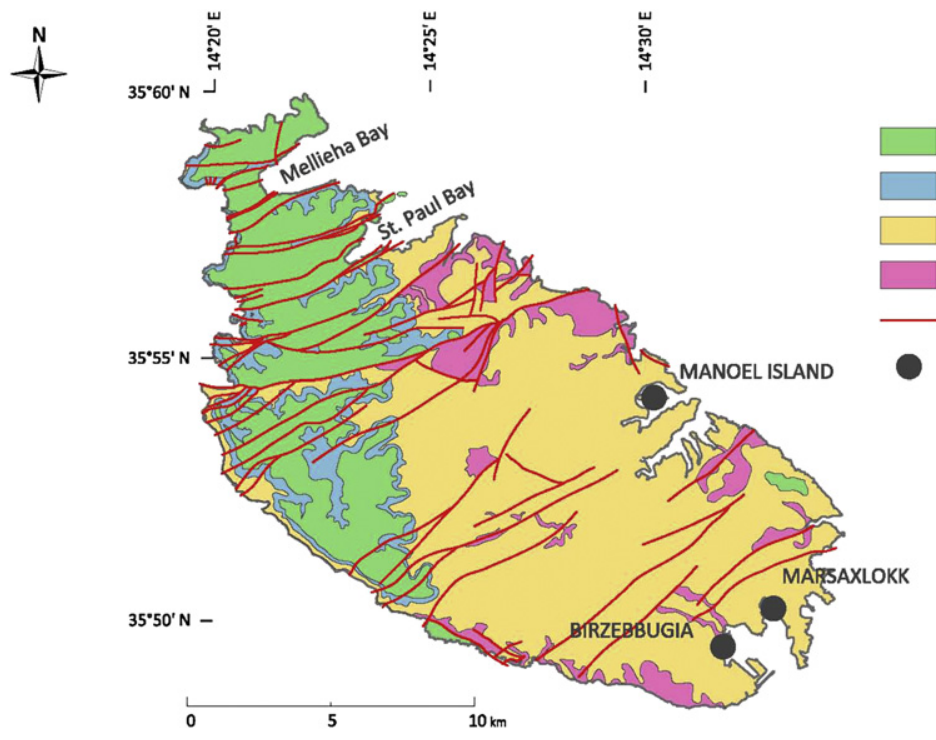

Upper Coralline Limestone Formation

Blue Clay Formation

Globigerina Limestone Formation

Lower Coralline Limestone Formation

faults

surveyed archaeological site

Fig. 2. Map of Malta showing the location of the studied sites (black circles). The geological map is redrawn from Pedley et al. (2002), and Devoto et al. (2012).

2011. Recent GPS surveys and moderate seismicity show that this area of the central Mediterranean is only affected by horizontal movements due to the interaction of the African and Eurasian continental plates (Serpelloni et al., 2007).

\section{Study area}

The island of Malta (Fig. 2) is part of the Maltese archipelago and is located in the middle of the Mediterranean Sea in the Sicily Channel (Fig. 1), between Sicily (90 km northward) and the African coasts (about $300 \mathrm{~km}$ westward). The geomorphology of the island has been well-described by Paskoff and Sanlaville (1978). It is strongly controlled by the horst and graben system developed during Miocene and Plio-Quaternary extensional stages. Bays correspond to downthrown blocks, and headlands correspond to uplifted blocks (Devoto et al., 2012). Semicircular coves, drowned sinkholes and other karst features are spread all over the island. The southern and eastern sectors of Malta are characterized by calanques: Valletta and the Birzebbugia harbour are rias, previously excavated by fluvial processes (Paskoff and Sanlaville, 1978).

The climate of Malta is typically Mediterranean, characterized by hot, dry and long summers, and warm and short winters. Weather and climate are strongly influenced by the sea and by the relatively flat morphology of the island, which does not favour rainfall. The average annual rainfall is $550 \mathrm{~mm}$ and rarely exceeds $800 \mathrm{~mm}$. Mean temperatures range from $12{ }^{\circ} \mathrm{C}$ to $27^{\circ} \mathrm{C}$.
Although Malta is a continental island connected to southwestern Sicily by a submerged ridge, palaebiogeographical evidence indicates that it remained completely isolated throughout most of the Pleistocene. During the main sea level lowering, the distance from the Sicilian coast was reduced to such an extent that mammals with high dispersal ability (elephants, hippopotamuses, deer, otter and a few small mammals) arrived on the island by a sweepstake dispersal route. Accordingly, both the Middle and the Late Pleistocene, still poorly known, Maltese faunas, although encompassing taxa descendant from Sicilian species, are less diversified and strongly unbalanced (see e.g. Storch, 1974; ZammitMaemple and de Bruijn, 1982; Palombo, 1986; Zammit-Maemple, 1989; Savona-Ventura and Mifsud, 1998; Hunt and Schembri, 1999).

\section{Material and methods}

The elevation of the submerged archaeological remains was measured following the Lambeck et al. (2004b), Antonioli et al. (2007) and Auriemma and Solinas (2009) methods. Field surveying consists of: 1) multiple measurements of the elevation of the significant archaeological markers with respect to the local sea level at the time of surveys (see Table 1);2) correction of measured elevations for atmospheric pressure and tides using tidal data from the nearest tide gauge station (Table 1); and 3) comparison of predicted (Lambeck et al., 2011) and observed sea levels inferred from the studied markers, which correspond to past sea levels at each location. Errors for ages and elevations of the selected

Table 1

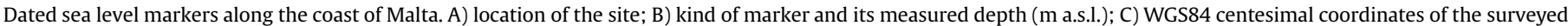

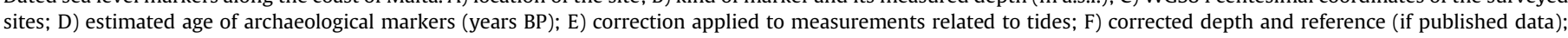
G) functional height; H) palaeo-sea level (measured + functional height); I) predicted sea level (from Lambeck et al., 2011).

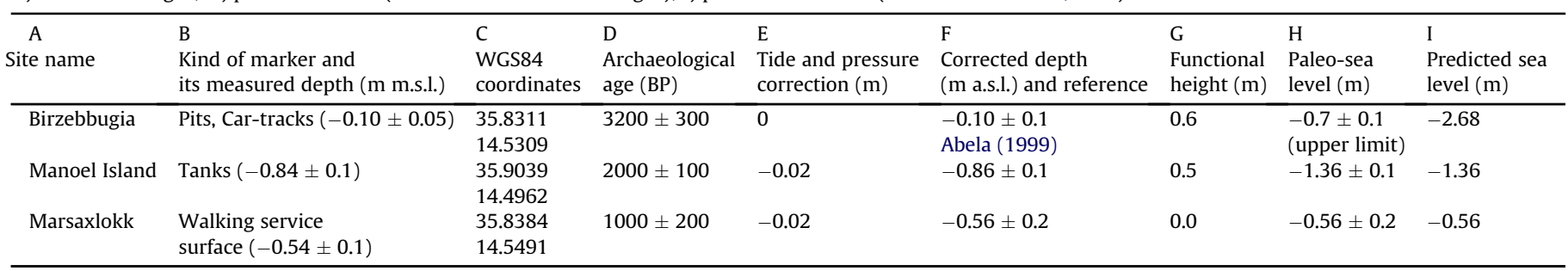


archaeological markers are evaluated. The latter are estimated from their functional heights on the basis of the archaeological interpretations, following Lambeck et al. (2004b) and Auriemma and Solinas (2009). Particularly, age errors derived from the attribution of architectural features, whereas elevation errors from multiple elevation measurements, tidal corrections and uncertainties on functional heights.

From the archaeological indicators, an area is assumed as tectonically stable if the elevation of the observational data falls along the predicted sea level curve (i.e. they show the same elevation for the same age, unless the errors shown by the error bars in the plots). Tectonic subsidence or uplift is considered if the elevations of the markers differ from the predicted sea level curve, for the same ages (i.e. data fall above or below the predicted sea level curve).

Topographic measurements of the marker elevations were collected using an invar rod during favourable sea surface conditions (wave amplitude $<5 \mathrm{~cm}$ ), in order to minimize reading errors. All measurements have been reduced to the local mean sea level applying tidal corrections at the surveyed sites, using tidal data retrieved at http://www.ioc-sealevelmonitoring.org/ from the nearest tide gauge station located at Malta, La Valletta. The Mediterranean Sea is a closed basin with small tidal range. Tidal amplitude is within a few tens of $\mathrm{cm}$ in Malta, and thus is not critical for this study.

The bathymetric data used for the palaeoshorelines reconstructions were derived from the General Bathymetric DatabaseGEBCO Chart of the Ocean (http://www.gebco.net/data_and_ products/gridded_bathymetry_data/). This database provides a bathymetric grid at 30 arc-second detail of system with reference to geographical coordinates, latitude and longitude in the WGS84
Datum Bathymetry. Topography was processed using the software Global Mapper 11 (www.globalmapper.com) in order to produce maps at different levels of detail. Maps were suitable to highlight the temporal evolution of palaeoshorelines and therefore the palaeomorphology of the narrow strip of land that once connected Malta to Sicily and the time of their detachment. The same method has already been used in similar tectonic contexts in other areas of the Mediterranean Sea, e.g. at Pianosa (Antonioli et al., 2011).

\section{Archaeological markers}

Three archaeological submerged or partially submerged structures were studied at Birzebbugia, Marsaxlokk (south Malta) and Manoel Island (Marsamxett Harbour, southeast Malta; Table 1; Figs. 3-5), spanning from the Bronze Age to Middle Age. These sites, which are generally not well preserved, have been recognised, surveyed and measured for size and depth, with respect to local mean sea level, for the first time. These sites are cut on soft Globigerina limestone rocks and located in sheltered zones (natural harbours). Archaeological remains at Marsaxlokk are exposed to storm waves of the southeastern Maltese coast (Gambin, 2003). Additionally, the nearby Victorian Age (middle to late 1800) baths were measured, in order to compare the elevations of ancient and recent marine structures.

\subsection{Birzebbugia pits}

The Birzebbugia archaeological site (Fig. 3a-d, Table 1) provides remains of activities related to the coastal zone during the Bronze Age (Zammit, 1928; Abela, 1999). In particular, two types of archaeological remains occur. The first are Bronze Age pits
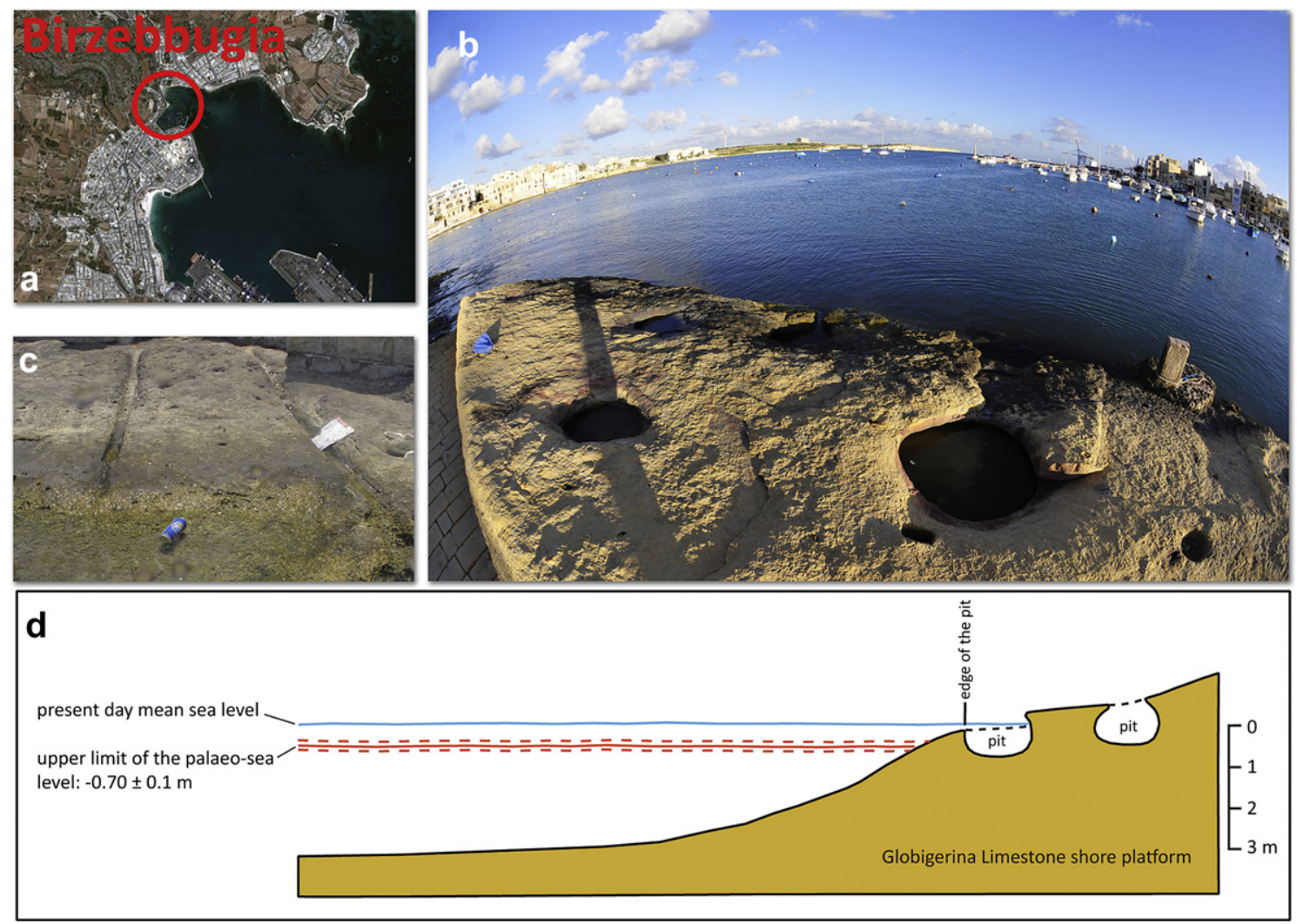

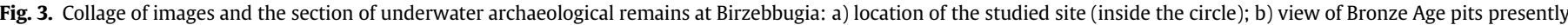

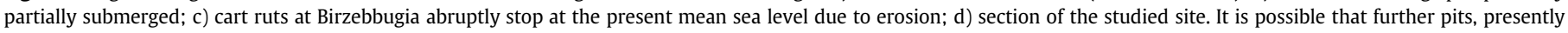
completely eroded, once existed at lower elevations. 

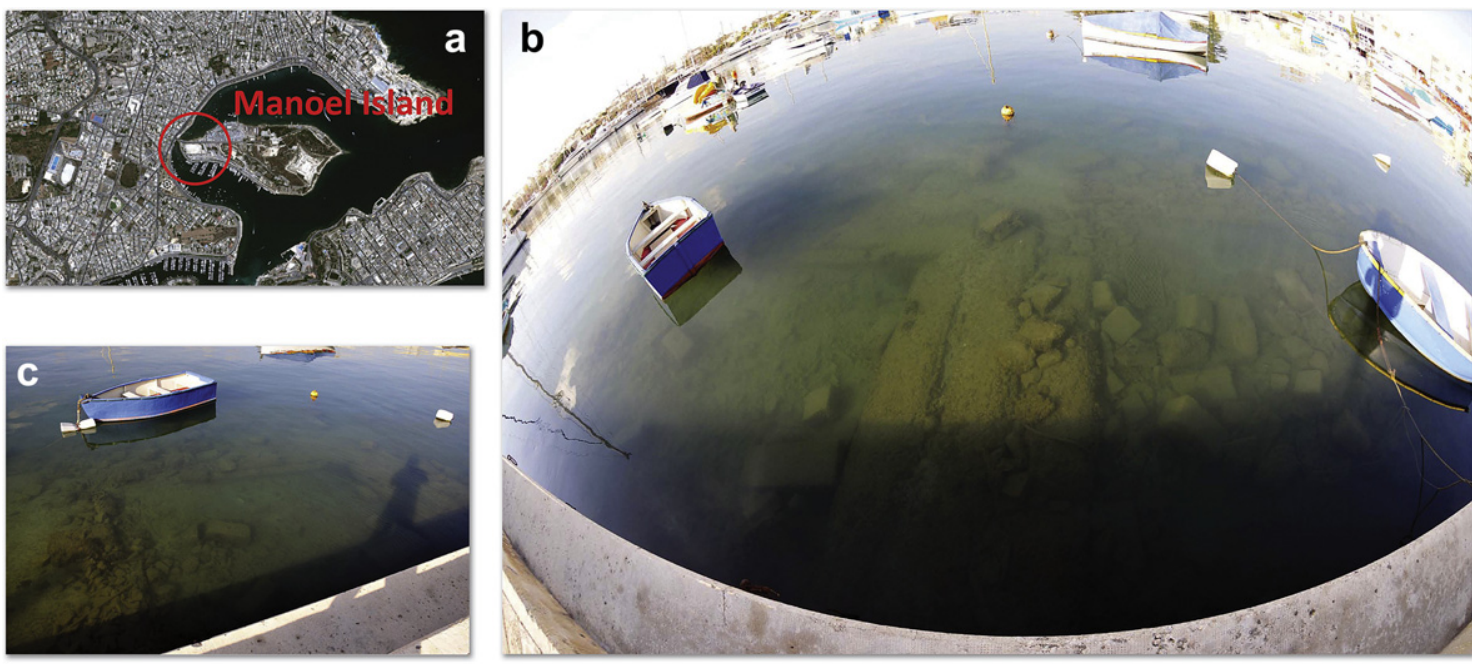

d
present day mean sea level

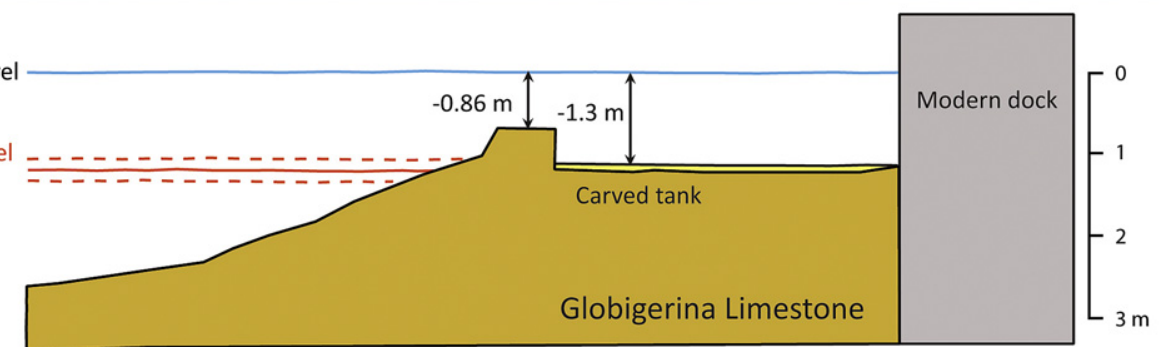

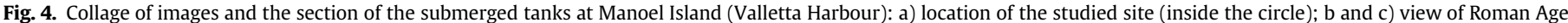
tanks; d) cross section.

(3500-2900 BP, Fig. 3a, b). They are located close to the shoreline and lie on the Globigerina Limestone platform, above present-day mean sea level or partially submerged. The pits are found very close to Borg in-Nadur, one of the main Bronze Age sites in Malta, which lends its name to the prehistoric phase that is characterized by settlement patterns and particular pottery types (Trump, 2002). Many other Bronze Age villages from the Borg in-Nadur phase contain similar features that have generally been deemed as storage pits (Trump, 2002).

The corrected depth of the bottom of the lowest submerged pit is $-0.90 \pm 0.1 \mathrm{~m}$ a.s.l., while the edge is at $-0.1 \pm 0.1 \mathrm{~m}$ a.s.l. (Fig. 3d). They have been found up to some meters above mean sea level. They had to be far enough above seawater in order to remain dry. This assumption allows evaluation of their original functionality to at least $0.6 \mathrm{~m}$ above sea level. Even if they are not coastal structures, they represent an upper limit of the Bronze Age sea level: in particular, sea level in the studied period had to be lower than $-0.7 \mathrm{~m}$ a.s.l. A schematic sketch of the structures is provided in Fig. 3d.

The second type of marker (Abela, 1999) is prehistoric carttracks, which consist of two pairs of parallel grooves deeply cut into limestone. They are almost completely eroded in the submerged part (about $-2 \mathrm{~m}$ a.s.l.) and almost completely covered by coastal buildings in the emerged part (Fig. 3c). Only $2 \mathrm{~m}$ of the tracks are still currently visible close to the pits site, and a few centimeters above the present-day sea level.

\subsection{Manoel Island structures}

At Manoel Island, 4 submerged structures have been examined (Fig. $4 a-d$ ). Based on their shape and size, they can be potentially dated to the Roman period. These are partly carved in Globigerina Limestone and partly built with blocks of the same rock, but presently are partly disconnected. The mean elevation of the bottom of the rectangular tanks is about $-1.3 \pm 0.1 \mathrm{~m}$ a.s.l., and the top of the blocks is at $-0.8 \pm 0.1 \mathrm{~m}$ a.s.l. (Fig. $4 \mathrm{~d}$ ). Although their use cannot be exactly determined, a working hypothesis is offered in the discussion section of this paper. Considering the mean elevation of the top of the blocks, the functional height is about $0.5 \mathrm{~m}$, in order to warrant the entrance of seawater in the tanks. Estimated Roman Age sea level was $-1.3 \pm 0.1 \mathrm{~m}$ a.s.l.

\subsection{Marsaxlokk underwater remains}

At Marsaxlokk, two previously unrecorded structures, $12 \mathrm{~m}$ long and $0.5 \mathrm{~m}$ wide, were discovered (Fig. $5 \mathrm{a}-\mathrm{e}$ ). They are slightly tilted toward the sea, and the elevation of their tops ranges between $-0.56 \pm 0.1 \mathrm{~m}$ a.s.l. inshore and $-0.93 \pm 0.1 \mathrm{~m}$ a.s.l. offshore. At the bottom end of these structures, the seafloor is at $-1.30 \pm 0.1 \mathrm{~m}$ a.s.l. Despite the shape and small size of these structures, which can be interpreted as walking service surfaces, they are more compact than the sandy sea bottom. As they could lie in an underwater position, functionality can be assessed as $0 \mathrm{~m}$. The structures could be built in the Middle Ages, and therefore the elevation of the inner block is representative of the Middle Age sea level.

\subsection{Victorian Age baths}

During the late nineteenth century, the rocky coasts of Malta were exploited again. No longer was the sea envisaged as something that was used solely for war and trade but many, especially 

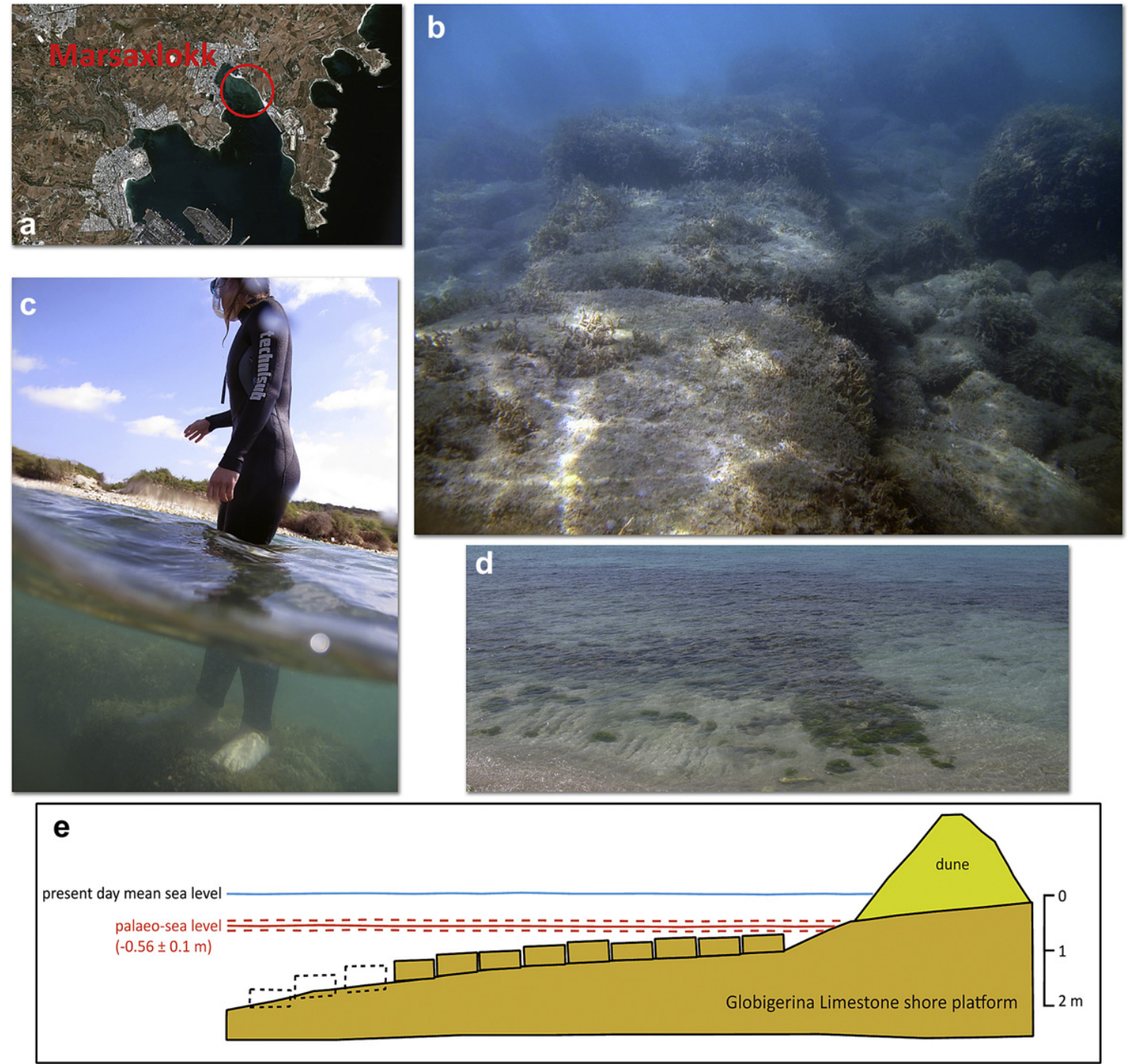

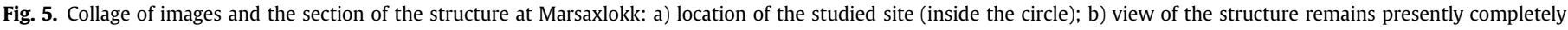
submerged; c) feet of the researcher are at about $-0.60 \mathrm{~m}$ a.s.l.; d) cross section.

the middle and upper classes of society, increasingly saw it as a place for recreation. In Malta, one way in which this phenomenon manifested itself was through the proliferation of swimming baths along various stretches of the Maltese coastline (Fig. 6a-c). Human-made structures directly carved on rocky outcrops are very common, because of their high erodibility. In general, these were cut onto solid rock and were approximately $1.3 \mathrm{~m}$ deep so as to allow people to stand up. Steps led down to the water and the baths were generally covered by wooden structures and/or canvas awnings. Open channels or small tunnels allowed water from the open sea to flow freely in and out of the baths. Some of these baths were built in high-energy zones, exposed to the strong northeasterly storms that blow in the winter. It is therefore not surprising to find that some sites are eroded more than others. This may give the impression that some of the sites are significantly older. However, all the bath complexes were built towards the end of the 19th and early 20th century.

English baths are generally well recognisable because of their architectural features (Fig. 6d). Usually they are built along the coast and are partly submerged. They were used by women to stay in a shallow and sheltered pool containing seawater. Their depth is about $-1.3 \pm 0.05 \mathrm{~m}$ a.s.l. Some have a threshold at $-0.8 \pm 0.05 \mathrm{~m}$ a.s.l., where the seawater can pass. The size is about $2 \times 3 \mathrm{~m}$.

\section{Archaeological markers: their use and relationships with the sea level}

The archaeological evidence is a matter of ongoing debate, emerged, partially, or completely submerged in sheltered or partially sheltered areas along the coast.

Regarding the Birzebbugia site, one of the latest contributions to this debate concentrates on what may be considered as the main archaeological feature related to the ancient textile industry in Malta, the rock-hewn pits in Birzebbugia. Sagona (1999) is in a quandary as to the date of origin of the pits, asking the question "are the vats Bronze Age features, as has long been accepted, or Punic in date?" Sagona also states that the pits were used for an industry based on textile dyeing. This suggestion may be discounted on the basis of a lack of evidence for substantial remains of Murex shells in this area or any other archaeological sites with Punic layers. The use as suggested by Trump (2002) that these pits were used as storage silos (for grain) must also be dismissed 

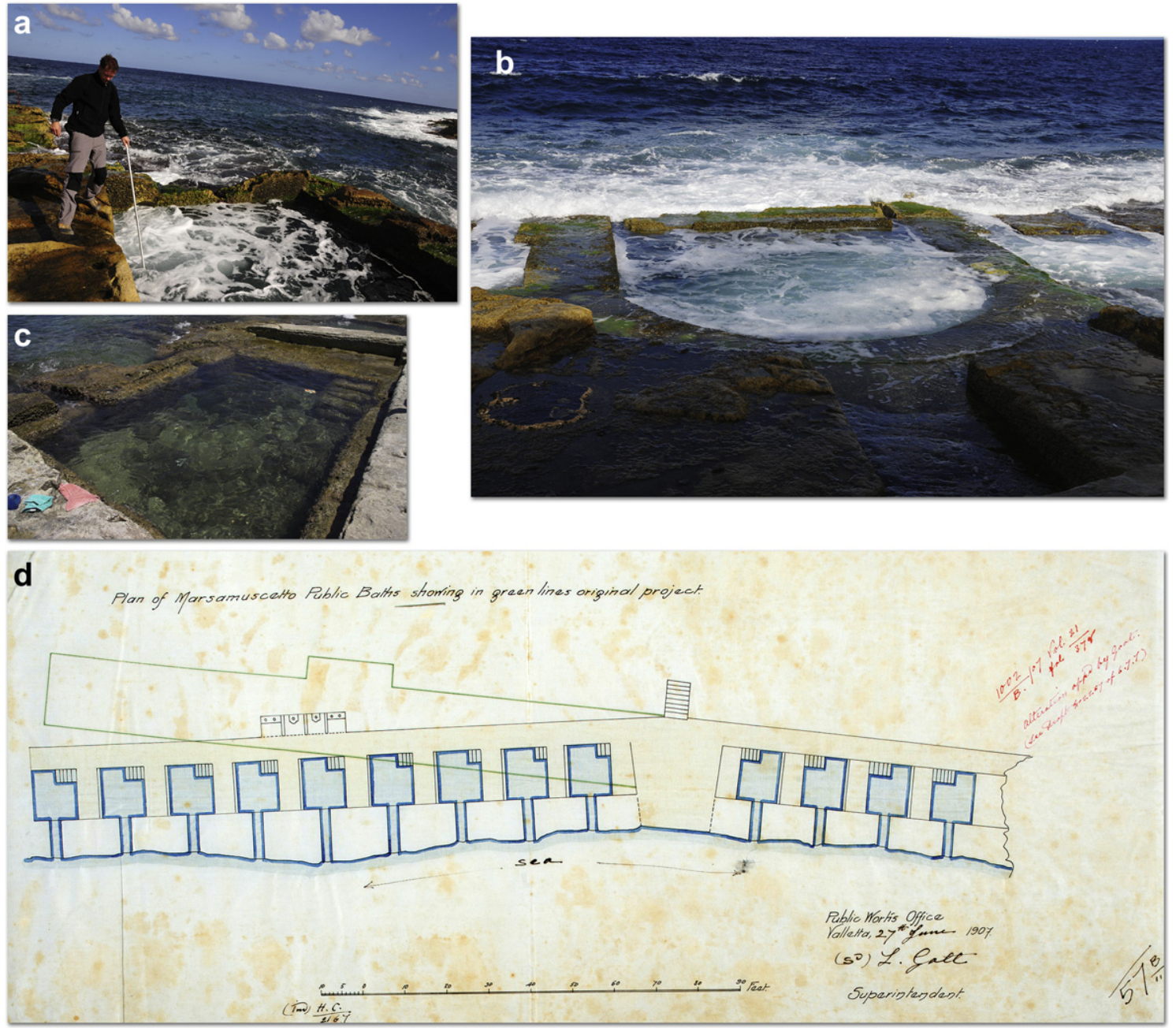

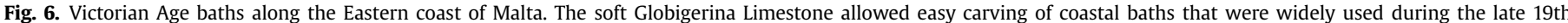
Century; a, b) view of baths at Sliema; c) coastal bath at San Paul Bay; d) English plan of Victorian Age baths at promenade by sea (Sliema).

because grain must be stored with humidity levels of less than 15 percent. The proximity to the sea of these features would not have been conducive to the maintenance of desired levels of humidity. Furthermore, the Bronze Age period in Malta was distinguished by the need for the islanders to seek settlements that were defensible from seaborne attacks. It is therefore highly unlikely that the same people who invested so much in constructing the nearby fortified settlement of Borg in-Nadur would have left a precious resource (grain) in unfortified silos by the sea.

An alternative use for these pits is that these may have formed part of a system used for the retting of flax. Some of the low laying areas around Birzebbugia and beyond are ideal, as per conditions cited by Horden and Purcell (2000), for the cultivation of flax. Alluvium from Wied Qoton and Wied Dalam helped create and maintain a soil advantageous to this form of agriculture, whereas the water supply from these same valleys would have been essential for the processing and retting of the plant.

It is therefore no coincidence that the cultivation and processing of flax on Malta during the late Middle Ages was partly concentrated in areas somewhat similar to Birzebbugia, such as Ghajn Selmet, near Salina Bay, and Misede, present-day Msida. Wettinger suggests that, "with Malta's then very imperfect drainage system for storm water one can easily understand the existence in such places of stagnant water, especially at the head of the numerous ports, bays and inlets" (Wettinger, 1982). The medieval place name for an area between Marsaxlokk and Birzebbugia, San Gorg tal-Ghadir, is described by Wettinger as a place "where there was a fountain used for the retting of flax" (Wettinger, 2000).

Roman Age remains are located in the southeastern and southern sector of Malta, at Manoel Island (Valletta Harbour). At Manoel Island, these structures are situated in the inner-reaches of Lazaretto Creek (Fig. 4a), one of Malta's few year-round anchorages. This inlet is protected from the winter storms and was used by ancient mariners as an anchorage and possibly even as a port. The massive urban development that has taken place in the surrounding area does not permit a detailed and accurate archaeological assessment. Despite the urbanization of the hinterland, there have been a number of ancient sites identified over the past decades. These include a burial complex discovered close to Manoel Island and a Roman tower on a hill overlooking this harbour. Numerous finds from the seabed, including partial amphorae and other ceramic objects, also confirm the use of Lazaretto Creek in ancient times.

To date, the only Roman ponds recorded in Malta were situated in Marsa. These were destroyed by dredging works during the harbour extension works in the 19th century. The underwater site on Manoel Island is dissimilar to any swimming baths datable to the 19th and 20th centuries. Furthermore, it is highly unlikely that 
swimming baths would have been built so close to the Quarantine Hospital. Should these structures prove to be ancient, it could well be that these are related to the production process of garum. There is little doubt that garum was produced in localities not dissimilar to Malta. For example, features such as those on the island of Lampedusa point to the production of garum on small islands (De Miro and Aleo Nero, 1992). On the southern coast of Sicily, tanks of similar size (but different construction methods) have been recorded in Poropalo (Bacci, 1985). The availability of fish and salt coupled with the vicinity of the works to the sea seems like a plausible working hypothesis for Malta.

At Marsaxlokk, a complex underwater structure has been discovered, now almost completely ruined. The Phoenician temple dedicated to Astarte on the hill dominating the bay was constructed over earlier remains that date to approximately $2500 \mathrm{BP}$, pointing to early use by humans of the bay and its surroundings. In ancient times, the harbour of Marsaxlokk was utilized by mariners as a place of refuge, trade and ritual. One of the main bodies of evidence found at the sanctuary consists of thousands of votive offerings to Astarte, who was patroness of seafarers. This affinity between sailors and sanctuary continued in the Roman period with Juno, assimilating the role of Astarte.

Due to the sedimentation in the bay and the vast growth of Posidonia meadows, it has not been possible to gather evidence for seafaring from an underwater context. However, in his Verrine orations, Cicero mentions the temple at Marsaxlokk as being very rich and well-known amongst seafarers from throughout the Mediterranean. He also suggests the possibility of the harbour being used by pirates to winter there. In the Middle Ages, the area was certainly used by medieval seafarers, as the Potolani such as Lo Compasso de Navegare of 1298 (Cassola, 1992) include clear references to Marsaxlokk.

The main difficulty of this harbour is its vulnerability to storms originating from the southeast. Such storms can blow during any time of the year, including summer. It would be difficult for a vessel to spend an entire winter in this bay without running major risks. The present-day inner harbour at Marsaxlokk was built on the site of large fish ponds that date back to the period of the Knights of St John (1530-1798). It is not unreasonable to assume that these fish ponds were built on the foundations of pre-existing harbour works. It has been suggested that there may have existed a cothon in this area (Bonanno, 2005).

The blocks surveyed in the course of this study are too small to represent the remains of a mole constructed in response to rising sea levels and/or sedimentation of the inner harbour. A more pertinent and alternative explanation, always linked to varying sea levels, is that of a pathway built across a stretch of low lying land to access the sea.

\section{Implications for Holocene sea level change}

Holocene sea level change is not expected to follow the eustatic curve, but varies across the Mediterranean because of isostasy and tectonics (Fig. 7). The new archaeological and geomorphological data presented in this study for the coasts of Malta, together with data published in previous works, provides new evidence of the tectonic behaviour of the island and on the timing and effects of relative sea level change. Despite the different typologies of archaeological sea level markers, found only in the southeastern coast of Malta, tentative reconstruction the sea level history was possible through comparison with other sea level markers, such as geomorphological features.

The impact of erosion processes on the preservation of archaeological, sedimentological and geomorphological markers is of primary importance. Almost all the eastern and southern

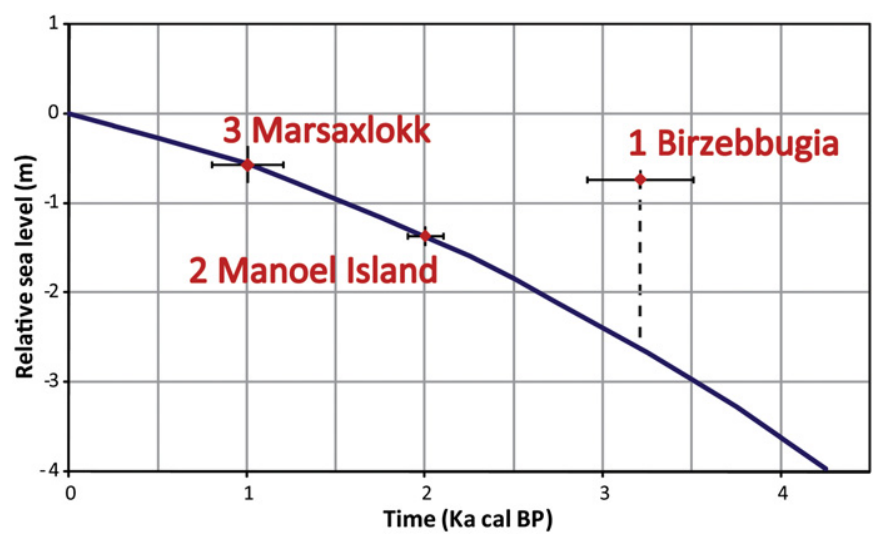

Fig. 7. Predicted sea level curve from Lambeck et al., 2011, with the observational point quoted in Table 1.

coast is cut on the soft Globigerina limestones. Lowering rates collected on Globigerina limestone shore platforms range from $0.74 \mathrm{~mm} / \mathrm{y}$ to $9.16 \mathrm{~mm} / \mathrm{y}$ (Micallef and Williams, 2009), one-two orders of magnitude higher than other intertidal sheltered area in the Mediterranean Sea (Furlani et al., 2009). High erosion rates are due both to the exposure of the island and to the nature of limestone outcrops. However, even human-made structures are affected by the same intense processes. For instance, even the recent Victorian Age baths are often strongly disturbed, and therefore ancient structures are surely spoilt. This could be the case for the Birzebbugia pits, where intertidal processes, both biological and mechanical, have partially destroyed the lower pits and may have completely removed deeper ones. There could also be pits hidden under sediment deposits present on the seabed in the area. At the same time, the presence of nineteenth-century (Victorian Age) swimming pools, which are architecturally welldefined (Fig. 6) but not always well-preserved, suggests that their position and relative poor preservation can easily cause misunderstandings, insomuch as they can be confused with earlier archaeological remains.

The archaeological data indicate that the island is tectonically stable along the vertical, at least since Roman times. Roman Age remains, despite their complex attribution concerning age and functionality, indicate sea level change. The Bronze Age pits are not definitive sea level markers as they are not coastal structures, but they do represent the upper limit of sea level during the studied period. Regarding the Manoel Island tanks and the Middle Age walking surface at Marsaxlokk, the comparison between their present depth, the altitude of the top of the blocks and the predicted sea level curve (Lambeck et al., 2011) suggests their elevation coincides roughly with the elevations predicted by the model (Fig. 7).

A well carved present-day notch occurs along the coasts of Malta on different lithologies: Lower Coralline Limestones and Upper Coralline Limestones. No presence of MIS 5.5 deposits was found by Paskoff and Sanlaville (1978) and in the present survey. The absence of MIS 5.5 deposits could be due to the exposure of the island and local weathering, preventing the preservation of rocks and deposits, in addition to the weakness of the geological units, generally easy to erode. However, the possible slightly submerged position of the Tyrrhenian deposits favours the complete erosion of MIS 5.5 deposits. This hypothesis, and the assumption that only minimal movement of sedimentary debris over the sea floor bedrock have occurred, allowed a palaeoenvironmental reconstruction of this region based on the available bathymetric maps and applying the predicted sea levels (Lambeck et al., 2011, Fig. 7) 
since the Last Glacial Maximum (LGM, 21.5 ka cal BP) describing the timing of the coastal evolution at Malta.

\section{Palaeoshorelines}

Figs. 8 and 9 show the evolution of the palaeoshorelines in this area of the central Mediterranean region and the limits of the land extension for different ages. These figures provide an overview of the spatial and temporal evolution of the land/sea extensions and depict the existing connections with the nearby coasts, thus roughly marking the timing of the detachment of Malta from Sicily.

The predicted sea level curve from Lambeck et al. (2011) was used to reconstruct the palaeoshorelines of the Sicily Channel; in particular it is identified with point 18 of Fig. 1 of that paper. Caruso et al. (2011) agree with the sea level prediction at $-130 \mathrm{~m}$ by Lambeck et al. (2011), and provided the first observational data of the maximum lowstand (MIS 2, LGM) for the Mediterranean Sea for a site offshore of the coast of Termini Imerese (Northern Sicily), that is located in an area considered tectonically stable. Sea level predictions are in agreement with observational data at $-127 \mathrm{~m}$, with a radiocarbon age of $21,823 \pm 219 \mathrm{BP}$. This data allows a reliable palaeogeographic reconstruction, although with some uncertainties, as the hypothesis is based on the existence of only minimal and negligible movements of the sedimentary debris on the sea floor and the absence of any tectonic movements. The continental shelf from which Malta and Gozo rose shows considerable areal extent and flat morphology, in contrast with the steep morphology of the continental shelves of southern Italy (Calabria, Basilicata and Eastern Sicily).

Taking into account the position of the sea level during the Last Glacial Maximum (LGM), the islands of Sicily and Malta were joined by a wide strip of land about $38 \mathrm{~km}$ wide and $105 \mathrm{~km}$ long (Fig. 8). Moreover, the palaeoshorelines of southwestern Sicily and northeastern Tunisia were distant only by about $45 \mathrm{~km}$.

During the late Pleistocene and Holocene, sea level was rising, and the island of Malta separated from Sicily between $14.5 \mathrm{ka}$ cal BP (sea level at $-100 \mathrm{~m}$ with respect to the present level) and $13.8 \mathrm{ka}$ cal BP (sea level at $-90 \mathrm{~m}$ with respect to the present level) (Fig. 9). During the Mesolithic (11 cal ka BP), the morphology of the island became similar to that of today. The $-90 \mathrm{~m}$ isobaths suggests that the distance between the palaeoshorelines of Sicily and Malta was only about $30 \mathrm{~km}$. The rising sea level up to the palaeoshoreline of $-70 \mathrm{~m}$ caused the disappearance of the small islands that were created from the land detachment, and at $12.4 \mathrm{ka}$ cal BP, Sicily and Malta were separated by about $62 \mathrm{~km}$ of sea.

The rising sea level continued to change the coastline of the rising island of Malta after its separation. Fig. 10 shows in detail the evolution of the island during the Holocene. The palaeoshorelines, reconstructed as a function of rising sea levels from $-70 \mathrm{~m}$ up to $-10 \mathrm{~m}$, show the marine transgression on the island of Malta, and the appearance and submergence of smaller islands. Between $7.2 \mathrm{ka}$ and $7 \mathrm{ka}$ (corresponding to the palaeoshorelines $-10 \mathrm{~m}$ and $-20 \mathrm{~m}$ respectively) the separation and formation of the island of Gozo took place. Today, Malta is about $80 \mathrm{~km}$ from the southernmost point of Sicily (Capo Passero).

\section{Late Pleistocene faunal dispersals}

During the Last Glacial Maximum (LGM), at about 24 ka BP, when sea level fell to about $-130 \mathrm{~m}$, the reconstructed palaeoshoreline indicates that the southwestern corner of Sicily and the Malta-Gozo insular system were connected by a land bridge. Additionally, even during the LGM, only some of the large and small mammals recorded in Sicily in the Castello faunal complex (ranging in age from about 20 to 11 ka BP, Masini et al., 2008) seems to have dispersed to Malta.

In the "Red earth layers" of Ghar Dalam cave, dating to about 18 ka (Zammit-Maemple, 1989), carnivores (Canis lupus, Vulpes vulpes), and a bear slightly reduced in size (referred to as Ursus cf. $U$. arctos), were reported for the first time together with other large mammals (Sus scrofa, Cervus elaphus), a bovid (likely Bos primigenius) and small mammals (Terricola sp., Crocidurasp.), which

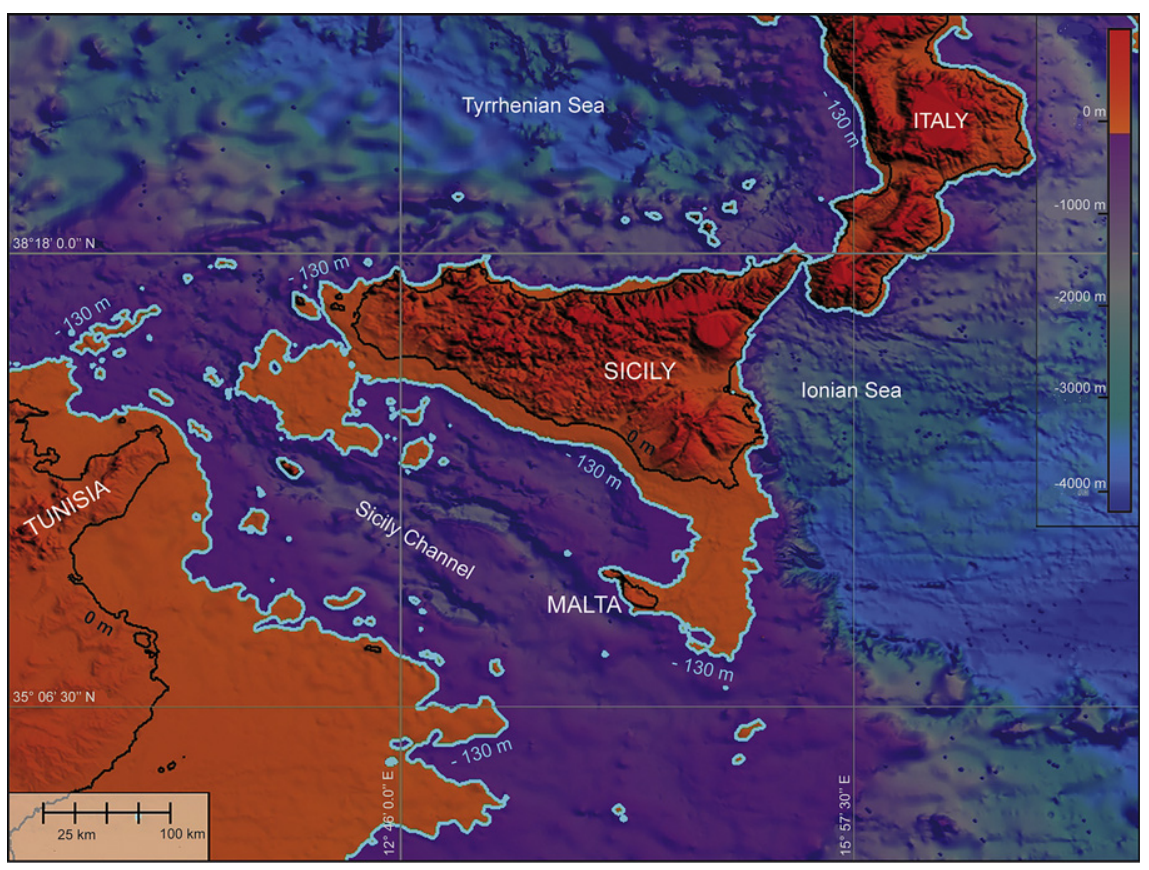

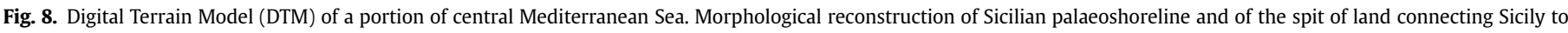
Malta during the LGM, last relative sea level rise (about $-130 \mathrm{~m}$ ). 


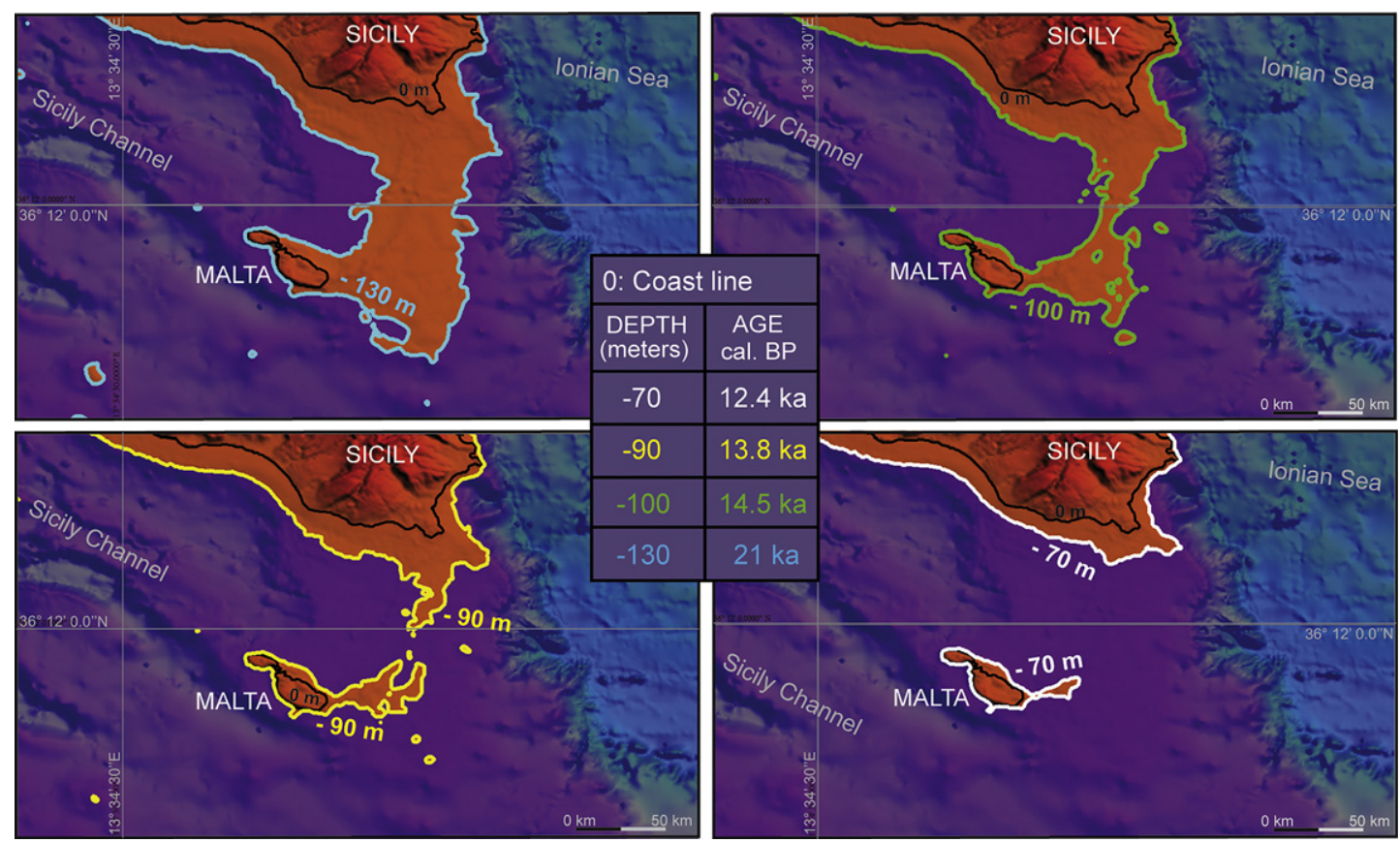

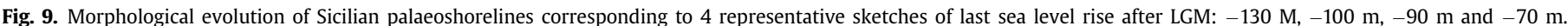
Recognition of ranges of the depth and corresponding age of the total separation of Malta from Sicily.

were present at the same time in Sicily. Other species recorded in Sicily, such as Erinaceus europeus, Apodemus sylvaticus, Lepus europeus, and Martes sp., apparently did not enter Malta, while the presence on the island of Equus hydruntinus is still uncertain.

The geological and geomorphological history of the studied area indicates that, during the late Quaternary, relative changes in sea level significantly influenced the connection between Sicily and the island of Malta. The question arises as when and how they separated. Consistent with the evidence from palaeoshorelines, the "Red earth layers" fossil record (Zammit-Maemple, 1989) indicates that during the LGM an emerged land bridge connected Sicily and Malta, although it acted as an ecological filter preventing some taxa from dispersal. Considering that in the Middle-early Late Pleistocene, only fauna with high dispersal ability are present and that a number of Sicilian species are missing (e.g. large carnivores such as Crocuta crocuta and Panthera leo, Sus, Bos, Bison, and perhaps even deer), there is ground to suppose that Sicily and Malta likely acted as two independent insular systems over the Pleistocene, and connection and faunal dispersal between Sicily and Malta were easier during the LGM than during the late Middle Pleistocene.
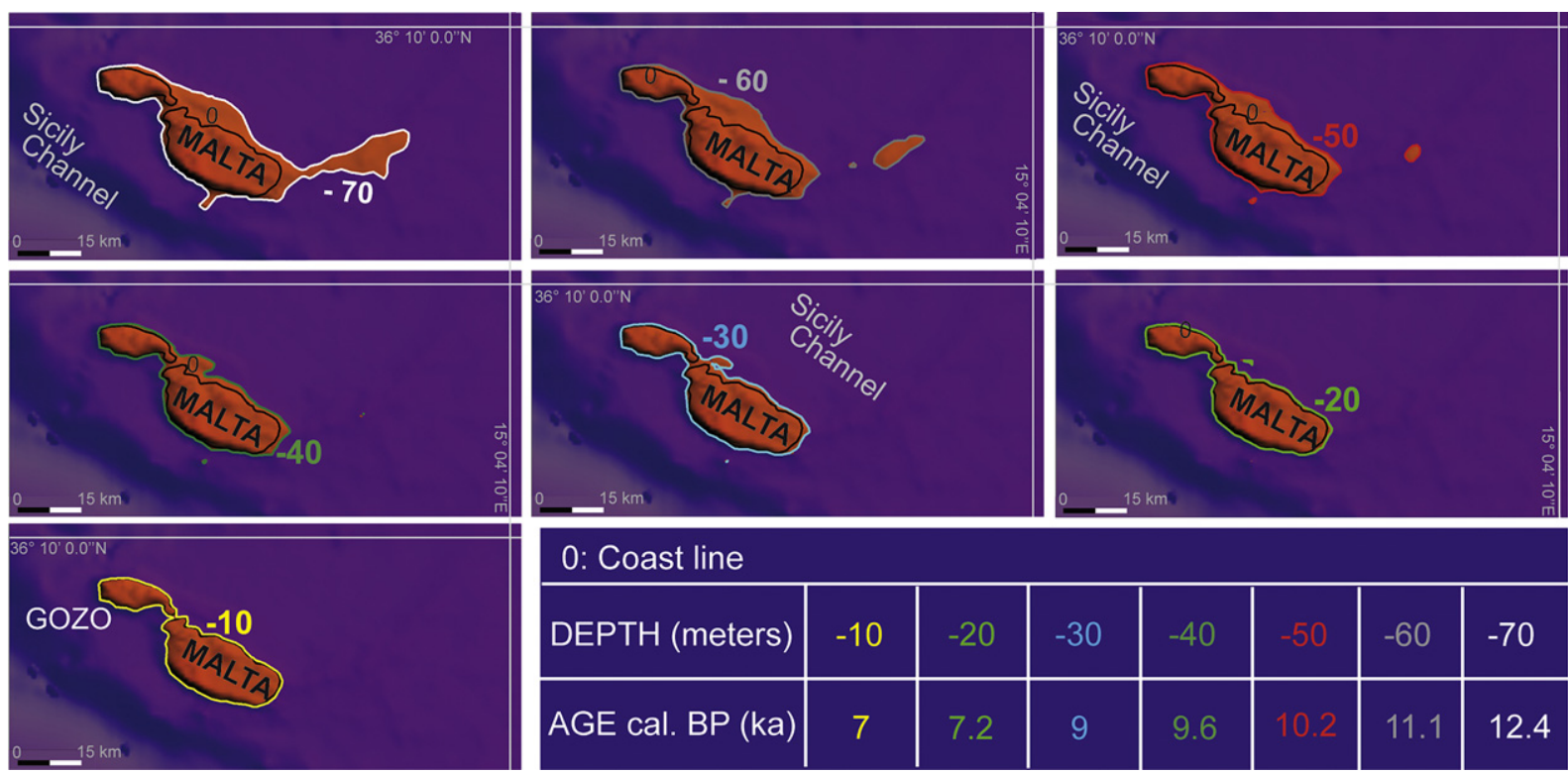

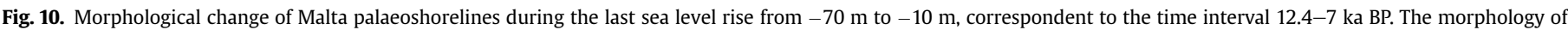
Malta coasts is similar to present since the last $11 \mathrm{ka}$ BP. 


\section{Conclusions}

Relative sea level changes in Malta have been studied starting from a detailed analysis of underwater archaeological remains located in the southern and southeastern side of the island. These remnants allowed estimation of the relative sea level changes and vertical displacements of the coast of the island of Malta since the Roman Age. Despite their complex attribution, Roman Age and Middle Age coastal structures roughly indicate that their elevations are in agreement with the predicted sea level curve of Lambeck et al. (2011).

During Roman time, sea level was $-1.36 \pm 0.1 \mathrm{~m}$, while in the Midde Ages it was at $-0.56 \pm 0.2 \mathrm{~m}$, in good agreement with previous estimations for the Mediterranean region (Lambeck et al., 2004b; Antonioli et al., 2007; Anzidei et al., 2011a, 2011b and; Toker et al., 2012). Geological data highlight that this area is tectonically stable along the vertical since the last $125 \mathrm{ka}$. The lack of MIS 5.5 deposits, as reported by Paskoff and Sanlaville (1978) and here confirmed, could be due to the exposure of the island or to the aforementioned slight vertical movements that removed any geological evidence. The relative stability of the studied area, together with the interpretation of the bathymetric maps, allow a tentative chronology of the palaeoenvironmental reconstruction of this area since the Last Glacial Maximum.

\section{Acknowledgements}

A very special thanks goes to Prof. Franco Cucchi of the Department of Mathematics and Geosciences of the University of Trieste and to Dr. John Schembri of the Department of Geography, University of Malta for helpful discussions. We are grateful to Prof. Mauro Soldati of the Department of Earth Sciences of the University of Modena and Reggio Emilia for funding support. Moreover, we thank Rita Auriemma for the useful archaeological considerations and Carmelo Monaco for the overall framework of the paper. We acknowledge SPLASHCOS Action TD0902: Submerged Research Action designated as COST Prehistoric Archaeology and Landscapes of the Continental Shelf.

\section{References}

Abela, R., 1999. Relative Sea Level Change: A Coastal Vulnerability Assessment of Malta. Unpublished Thesis, University of Malta, 217 p.

Antonioli, F., Anzidei, M., Lambeck, K., Auriemma, R., Gaddi, D., Furlani, S., Orrù, P., Solinas, E., Gaspari, A., Karinja, S., Kovacić, V., Surace, L., 2007. Sea level change during Holocene from Sardinia and northeastern Adriatic (Central Mediterranean Sea) from archaeological and geomorphological data. Quaternary Science Reviews 26, pp. 2463-2486.

Antonioli, F., Amorosi, A., Bondesan, A., Braitenberg, C., Dutton, A., Ferranti, L., Fontana, A., Fontolan, G., Furlani, S., Lambeck, K., Mastronuzzi, G., Monaco, C., Orrù, P., 2009. A review of the Holocene sea-level changes and tectonic movements along the Italian coastline. Quaternary International 206, 102-133.

Antonioli, F., D’Orefice, M., Ducci, S., Firmati, M., Foresi, L.M., Graciotti, R., Pantaloni, M., Perazzi, P., Principe, C., 2011. Palaeogeographic reconstruction of northern Tyrrhenian coast using archaeological and Geomorphological markers at Pianosa Island (Italy). Quaternary International 232, 31-44.

Anzidei, M., Antonioli, F., Lambeck, K., Benini, A., Soussi, M., Lakhdar, R., 2011a. New insights on the relative sea level change during Holocene along the coasts of Tunisia and western Libya from archaeological and geomorphological markers. Quaternary International 232, 5-12.

Anzidei, M., Antonioli, F., Benini, A., Lambeck, K, Sivan, D., Serpelloni, E., Stocchi, P. 2011b. Sea level change and vertical land movements since the last two millennia along the coasts of southwestern Turkey and Israel. Quaternary International 232, 13-20.

Auriemma, R., Solinas, E., 2009. Archaeological remains as sea level change markers: a review. Quaternary International 206, 134-146.

Bacci, G.M., 1985. Scavi e Ricerche a Avola, Grammichele, Portopalo, Taormina. Kokalos 30-31, 711-725.

Biolchi, S., Gambin, T., Gauci, R., Antonioli, F., Furlani, S., Anzidei, M., Devoto, S., 2011. Late Holocene sea level change in Malta. Il Quaternario - Italian Journal of Quaternary Sciences 24, 20-22.
Bonanno, A., 2005. Malta: Phoenician, Punic and Roman. Midsea Books, Malta p. 359.

Caruso, A., Cosentino, A., Pierre, C., Sulli, A., 2011. Sea-level changes during the last 41,000 years in the outer shelf of the southern Tyrrhenian Sea: evidence from benthic foraminifera and seismostratigraphic analysis. Quaternary International 232, 122-131.

Cassola, A., 1992. The Maltese Toponomy in three ancient Italian Portulans (1296-1490). Al-Masaq Studia Arabo-Islamica Mediterranea. International Journal of Arabo-Islamic, Mediterranean Studies 5, 47-64.

Catalano, R., Infuso, S., Sulli, A., 1994. The submerged Alpidic chain from southern Sardinia shelf to the Pelagian rifting: tectonic history. Bollettino di Geofisica Teorica ed Applicata 36, 139-158.

Catalano, R., Franchino, A., Merlini, S., Sulli, A., 2000. A crustal section from the North Algerian to the Ionian ocean (Central Mediterranean). Memorie della Società Geologica Italiana 55, 71-85.

Dart, C.J., Bosence, D.W.J., McClay, K.R., 1993. Stratigraphy and structure of the Maltese graben system. Journal of the Geological Society 150, 1153-1166.

Della Vedova, B., Pellis, G., Pinna, E., 1989. Studio geofisico dell'area di transizione tra i Mar Pelagico e la Piana Abissale dello Jonio. Atti $8^{\circ}$ Conv. Ann. GNGTS, 543-558.

De Miro, A., Aleo Nero, C., 1992. Lampedusa: un impianto per la lavorazione de pesce. In: V Rassegna di archeologia subacquea, Atti, Giardini Naxos (Messina), 19-21 ottobre 1990 , pp. 45-53.

Devoto, S., Biolchi, S., Bruschi, M.V., Furlani, S., Mantovani, M., Piacentini, D., Pasuto, A. Soldati, M., 2012. Geomorphological map of the NW Coast of the Island of Malta (Mediterranean Sea). Journal of Maps. doi:10.1080/17445647.2012.668425.

Finetti, I., Del Ben, A., 1986. Geophysical study of the Tyrrhenian opening. Bollettino di Geofisica Teorica ed Applicata 28, 75-155.

Flemming, N.C., 1969. Archaeological Evidence for Eustatic Changes of Sea Level and Earth Movements in the Western Mediterranean in the Last 2000 years. Geological Society of America. Special Paper 109.

Furlani, S., Cucchi, F., Forti, F., Rossi, A., 2009. Comparison between coastal and inland Karst limestone lowering rates in the northeastern Adriatic Region (Italy and Croatia). Geomorphology 104, 73-81.

Galea, P., 2008. Seismic history of the Maltese Islands and considerations on seismic risk. Annals of Geophysics 50, 725-740.

Gambin, T., 2003. Islands of the Middle Sea. An Archaeology of a Coastline. Evolucion Paleoambiental de los Puertos y fondeaderos antiguos en el Mediterraneo occidental. In: Alicante, De Maria, L., Turchietti, R. (Eds.), De Maria L, Turchietti R. 2003. I seminario. El Patrimonio arcqueologico submarine y los puertos antiguos. 14-15 noviembre 2003, pp. 127-146.

Grasso, M., Mazzoldi, G., Torelli, L., 1993. Structural and stratigraphic framework of the Tunisian shelf surroundings the islands of Lampione and Lampedusa (Pelagian Sea). In: Max, M.D., Colantoni, P. (Eds.), Geological Development of the Sicilian-Tunisian Platform. Report Marine Science 58. Unesco, Paris, pp. 65-70.

Horden, P., Purcell, N., 2000. The Corrupting Sea: a Study of Mediterranean History. Oxford and Malden (Mass.). Blackwell.

Hunt, C.O., 1996. Quaternary deposits in the Maltese islands: a microcosm of environmental change in Mediterranean lands. GeoJournal 41, 101-109.

Hunt, C.O., Schembri, P.J., 1999. Quaternary environments and biogeography of the Maltese islands. In: Mifsud, A., Savona Ventura, C. (Eds.), Facets of Maltese Prehistory. The Prehistoric Society of Malta, Malta, pp. 1-39.

Illies, J.H., 1981. Graben formation: the Maltese Islands - a case study. Tectonophysics $73,151-168$.

Jongsma, D., Woodside, J.M., King, G.C.P., Van Hinte, J.E., 1987. The Medina Wrench: a key to the kinematics of the Central and Eastern Mediterranean over the past 5 Ma. Earth and Planetary Sciences Letters 82, 87-106.

Lambeck, K., Antonioli, F., Purcell, A., Silenzi, S., 2004a. Sea level change along the Italian coast for the past 10,000 yrs. Quaternary Science Reviews 23,1567-1598.

Lambeck, K., Anzidei, M., Antonioli, F., Benini, A., Esposito, E., 2004b. Sea level in Roman time in the central Mediterranean and implications for modern sea level rise. Earth and Planetary Science Letters 224, 563-575.

Lambeck, K., Purcell, A., 2005. Sea-level change in the Mediterranean Sea since the LGM: model predictions for tectonically stable areas. Quaternary Science Reviews 24, 1969-1988.

Lambeck, K., Antonioli, F., Anzidei, M., Ferranti, L., Leoni, G., Silenzi, S., 2011. Sea level change along the Italian coasts during Holocene and prediction for the future. Quaternary International 232, 250-257.

Magri, O., 2006. A geological and geomorphological review of the Maltese islands with special references to the coastal zone. Territoris 6, 7-26.

Masini, F., Petruso, D., Bonfiglio, L., Mangano, G., 2008. Origination and extinction patterns of mammals in three central Western Mediterranean Islands in the Late Miocene to Quaternary. Quaternary International 182, 63-79.

Micallef, A., Williams, A.T., 2009. Shore platform denudation measurements along the Maltese coastline. Journal of Coastal Research Special Issue 56, 737-741.

Oil Exploration Directorate, 1993. Geological Map of the Maltese Islands, Sheet 1 Malta - Scale 1:25000. Office of the Prime Minister, Valletta.

Paskoff, R., Sanlaville, P., 1978. Observations geomorphologiques sur les cotes de l'archipel Maltais. Zeitschrift fur Geomorphologie 22, 310-328.

Palombo, M.R., 1986. I grandi mammiferi pleistocenici delle isole del Mediterraneo: tempi e vie di migrazione. Bollettino della Società Paleontologica Italiana 24 201-204.

Pedley, H.M., House, M.R., Waugh, B., 1978. The geology of the Pelagian blocks: the Maltese Islands. In: Nairn, A.E.M., Kanes, W.H., Stehli, F.G. (Eds.), The Ocean Basins and Margins. The Western Mediterranean, vol. 4B. Plenum Press, London, pp. 417-433. 
Pedley, M., 2011. The Calabrian Stage, Pleistocene highstand in Malta: a new marker for unravelling the Late Neogene and Quaternary history of the islands. Journal of the Geological Society 168 (4), 913-926.

Pedley, M., Clarke, M.H., Galea, P., 2002. Limestone Isles in a Crystal Sea. In: The Geology of the Maltese Islands. P.E.G, Malta.

Pirazzoli, P.A., Laborel, J., Stiros, S.C., 1996. Coastal indicators of rapid uplift and subsidence: examples from Crete and other eastern Mediterranean sites. Zeitschrift für Geomorphologie N.F 102, 21-35 (Suppl. Bd).

Sagona, C., 1999. Silo or Vat? Observations on the ancient textile industry in Malta and early Phoenician interests in the island Oxford. Journal of Archaeology 18, 23-60.

Savona-Ventura, C., Mifsud, A., 1998. Ghar Dalam cave, a review of the sediments on the cave floor stratigraphy. Xyenza 3,5-12.

Scicchitano, G., Antonioli, F., Castagnino Berlinghieri, E.F., Dutton, A., Monaco, C. 2008. Submerged archaeological sites along the Ionian coast of south-eastern Sicily and implications with the relative sea level change during the late Holocene. Quaternary Research 70, 26-39.

Serpelloni, E., Vannucci, G., Pondrelli, S., Argnani, A., Casula, G., Anzidei, M., Baldi, P., Gasperini, P., 2007. Kinematics of the Western Africa - Eurasia Plate Boundary from Focal Mechanisms and GPS data. Geophysical Journal International 169, 1180-1200.

Storch, G., 1974. Quartare Fledermaus-faunen von der Insel Malta. Senckenbergiana Lethaea 55, 407-434.

Toker, E., Sivan, D., Stern, E., Shirman, B., Tsimplis, M., Spada, G., 2012. Evidence for centennial scale sea level variability during the Medieval Climate Optimum (Crusader Period) in the eastern Mediterranean. Earth and Planetary Science Letters 315-316, 51-61.

Trenchmann, C.T. 1938. Quaternary conditions in Malta. Geological Magazine 4 (75), 1-26.

Trump, D.H., 2002. Malta: Prehistory and Temples. Midsea Books, Malta, p. 319.

Wettinger, G., 1982. Agriculture in Malta in the Late Middle Ages. In: Proceedings of History Week, 1981, Malta, 1-48.

Wettinger, G., 2000. Place-names of the Maltese Islands ca.1300-1800 (Malta: PEG). Zammit, T., 1928. Prehistoric cart-tracks in Malta. Antiquity 2 (5), 18-25.

Zammit-Maemple, G., 1989. Ghar Dalam Cave and Deposits. Mid-Med Bank, Malta. Zammit-Maemple, G., de Bruijn, H., 1982. The Plio/Pleistocene Gliridae from the Mediterranean Islands reconsidered. Proceedings of the Koninklijke Nederlandse Akademie van Wetenschappen B85, 113-128. 